\title{
Sexual agglutination substances require a 'carrier' glycoprotein for integration into the cell wall of Saccharomyces cerevisiae
}

\author{
Makoto Yamaguchi, $†$ Kazuo Yoshidał and Naohiko Yanagishima\$
}

Author for correspondence: Kazuo Yoshida. Tel: +81 82424 7455. Fax: + 81824240734.

Biological Institute, Faculty of Science, Nagoya University, Chikusa-ku, Nagoya 464, Japan

\begin{abstract}
Sexual agglutination, caused by agglutination substance (AS) on a and $\alpha$ cell walls, is the first indispensable step of the mating reaction in ascosporogenous yeasts including Saccharomyces cerevisiae. The AS biosynthetic process in S. cerevisiae was investigated by pulse label-chase experiments with analysis by polyacrylamide gel electrophoresis (PAGE) for $16 \mathrm{~h}$ in the presence of urea. Because of its low mobility, AS can be separated from other proteins by prolonged PAGE. Nascent AS was integrated into cell walls after it linked covalently to a 'carrier' glycoprotein. The results suggest that the 'carrier' is synthesized stepwise through three distinct precursors $(\mathrm{III} \rightarrow \mathrm{II} \rightarrow \mathrm{I})$. The 'carrier' glycoprotein (I) and its precursors (II, III) were synthesized in both $a$, $\alpha$ haploid and a/ $\alpha$ diploid cells. The $\boldsymbol{N}$-glycosylation linkage inhibitor, tunicamycin, and protein synthesis inhibitor, puromycin, inhibited the III to I maturation. The results indicated that both the 'carrier' and the nascent active site of AS linked to the 'carrier' are integrated into the wall in a haploid cell while the 'carrier' alone is integrated in a diploid cell.
\end{abstract}

Keywords: Saccharomyces cerevisiae, sexual agglutination, agglutination substance, biosynthesis, carrier glycoprotein

\section{INTRODUCTION}

The first step in the mating reaction in ascosporogenous yeasts is sexual cell agglutination, which is caused by agglutination ligand substances (agglutination substances, ASs, or agglutinins) on the cell surface (Yanagishima, 1984; Yoshida et al., 1989). In Saccharomyces cerevisiae, the co-dominant alleles $M A T \mathbf{a}$ and $M A T \alpha$ confer $\mathbf{a}$ - and $\alpha$-mating types, respectively. The $c i s$-acting $M A T$ locus controls expression of various mating-typespecific genes (MacKay \& Manney, 1974; Strathern et al., 1981), including production of the cell-surface AS (Tohoyama \& Yanagishima, 1982). Sexual ASs from the cell wall (wAS) (Yoshida et al., 1976; Yanagishima \& Yoshida, 1981) and cytoplasm (cAS) (Yamaguchi et al., $1982,1984)$ have been isolated and characterized. The structural gene $(A G \alpha 1)$ of $\mathrm{AS}$ is located on chromosome

\footnotetext{
†Present address: Institute of Technology, Shimizu Corporation, 4-17, Etchujima, 3-Chome, Koto-ku, Tokyo 135, Japan.

$\ddagger$ Present address: Department of Biological Science, Faculty of Science, Hiroshima University, Higashi-Hiroshima 724, Japan.

ऽDeceased.
}

Abbreviations: AS, agglutination substance; PAS, periodic acid/Schiff; PBS, $10^{2} \mathrm{M}$ phosphate buffer solution, $\mathrm{pH}$ 5.5.
X (Suzuki \& Yanagishima, 1986). Recently, the AS gene was cloned and sequenced (Lipke et al., 1989).

In this paper, we describe the possible synthetic process of AS in S. cerevisiae.

\section{METHODS}

Strains. Prototrophic haploid strains of S. cerevisiae, T55 (a) and T56 $(\alpha)$, having constitutive sexual agglutinability, and diploid strain T556 (a/ $\alpha)$, were used (Tohoyama \& Yanagishima, 1982).

Enzymes and chemicals. Tunicamycin was purchased from Sigma, cycloheximide, puromycin and bovine pancreas trypsin from Boehringer-Mannheim, Zymolyase-60000 ( $\beta$-1,3glucanase) from Seikagaku Kogyo, Tokyo, Japan, L$\left.{ }^{35} \mathrm{~S}\right]$ methionine from New England Nuclear, and $\mathrm{D}-[2-$ $\left.{ }^{3} \mathrm{H}\right]$ mannose from Amersham.

Labelling of cells with radioisotopes. In order to label the cells with $\left[{ }^{3} \mathrm{H}\right]$ mannose, $50 \mu \mathrm{l}$ of cell suspension, cultured on synthetic complete medium (SC medium) (Yamaguchi et al., 1984) to the mid-exponential phase (about $5 \times 10^{6}$ cells $\mathrm{ml}^{-1}$ ), was inoculated into $5 \mathrm{ml} \mathrm{SC}$ medium with $\left[{ }^{3} \mathrm{H}\right]$ mannose $\left(0.444 \mathrm{MBq} \mathrm{ml}^{-1}\right)$ and cultured with stirring at $28^{\circ} \mathrm{C}$ for $16 \mathrm{~h}$. In the pulse-chase experiments with $\left[{ }^{35} \mathrm{~S}\right]$ methionine, cells that had been cultured in $5 \mathrm{ml} \mathrm{SC}$ medium to the mid-exponential phase (about $5 \times 10^{6}$ cells $\mathrm{ml}^{-1}$ ), were pulse-labelled with 
$\left[{ }^{35} \mathrm{~S}\right]$ methionine $\left(0 \cdot 222 \mathrm{MBq} \mathrm{ml}^{-1}\right)$. The cells were then washed twice with $130 \mathrm{mM}$ unlabelled methionine and once with SC medium. The washed cells were chased in SC medium without radioactive label. If inhibitors were added, cells were first converted to protoplasts as described below, and then were cultured in SC medium containing $5 \mathrm{ml} 0.8 \mathrm{M}$ sorbitol owing to the difficulty in inhibitor uptake.

Separation and determination of labelled agglutination substance. Labelled cells were washed twice with $130 \mathrm{mM}$ unlabelled methionine and once with protoplast buffer $(0.1 \mathrm{M}$ citric acid/0.2 $\mathrm{M} \mathrm{Na}_{2} \mathrm{HPO}_{4}$ buffer containing $0.8 \mathrm{M}$ sorbitol; $\mathrm{pH} 6 \cdot 0$ ). To the cells, $2 \mathrm{ml}$ of an isotonic protoplast buffer containing cycloheximide $\left(100 \mu \mathrm{g} \mathrm{ml}^{-1}\right)$ and $200 \mu \mathrm{l} \mathrm{Zymolyase}$ solution $\left(0.6 \mathrm{mg} \mathrm{m}^{-1}\right)$ (containing $2 \mathrm{mM} \mathrm{EDTA} ; \mathrm{pH} 7 \cdot 2$ ) were added. Cell suspensions were incubated at $28^{\circ} \mathrm{C}$ for $1 \mathrm{~h}$ to allow cell wall digestion. The protoplasts were washed twice with protoplast buffer, and then $1 \mathrm{ml}$ PBS containing $2 \mathrm{mM}$ phenylmethylsulfonyl fluoride (PMSF) was added. After standing at $0{ }^{\circ} \mathrm{C}$ for $30 \mathrm{~min}$, the protoplast suspension was sonicated for cell disruption. Since $\mathrm{AS}$ is heat-stable, the sonicated suspension was heated at $100{ }^{\circ} \mathrm{C}$ for $7 \mathrm{~min}$ in a water bath to inactivate degradative enzymes and was immediately centrifuged at $1500 \mathrm{~g}$ for $10 \mathrm{~min}$ (Yamaguchi et al., 1982). The $\mathrm{pH}$ of the resultant supernatant fraction was adjusted to 2 with conc. $\mathrm{HCl}$, and then the fraction was centrifuged at $56000 \mathrm{~g}$ for $30 \mathrm{~min}$ at $4{ }^{\circ} \mathrm{C}$. The supernatant fraction was neutralized with $10 \mathrm{M} \mathrm{KOH}$ and was adjusted to a final urea concentration of $8 \mathrm{M}$. The resultant sample was subjected to PAGE with a $0.5 \times 8 \mathrm{~cm}$ disc in the presence of $8 \mathrm{M}$ urea at $3 \mathrm{~mA}$ per gel for $16 \mathrm{~h}$ (Yamaguchi et al., 1982, 1984). The prolonged electrophoretic run separated low-mobility AS from other contaminant proteins, which ran through. We adopted disc gels because of the convenience in sample extraction from gel slices and the higher loading capacity.

After the electrophoretic run, the gel was frozen using dry ice and cut into $1 \mathrm{~mm}$ slices with a razor blade. Half of the slices were used for radioactivity measurements. Each slice was

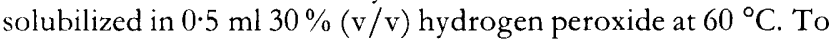
the solution, $3 \mathrm{ml}$ ACS-II (Amersham) was added, and then the radioactivity was measured in a liquid scintillation spectrometer (LKB 3800)

Preparation of crude a pheromone. Ten millilitres of T55 (a) cell culture, grown to early exponential phase in YHG medium (Tohoyama \& Yanagishima, 1982), was inoculated into 10 litres of MMT medium, followed by aeration for $2 \mathrm{~d}$ (Yoshida $e t$ al., 1976). Cells were removed by centrifugation and the culture supernatant was applied onto a CG 50 column to prepare partially purified a pheromone according to Tohoyama \& Yanagishima (1982).

Binding activity of labelled agglutination substance to cells. PAGE gel slices corresponding to labelled AS were homogenized and centrifuged. The supernatant was added to sexually agglutinable a or $\alpha$ tester cells $\left(10^{7}\right.$ cells $\left.\mathrm{ml}^{-1}\right)$ as described by Yamaguchi et al. (1982). The treated tester cells were collected onto Whatman $3 \mathrm{MM}$ filter paper, washed three times with $5 \%(\mathrm{w} / \mathrm{v})$ TCA and once with ethanol, and then the radioactivity was measured using PPO-POPOP xylene-based scintillator.

Peptide mapping. The half of the labelled gel slices not used for radioactivity measurement were used for this procedure. Slices corresponding to AS were collected and submerged in a $150 \mu \mathrm{l}$ solution of trypsin $\left(1 \mathrm{mg} \mathrm{ml}^{-1}\right)$ in $50 \mathrm{mM}$ ammonium hydrogen carbonate $\left(\mathrm{NH}_{4} \mathrm{HCO}_{3}\right)(\mathrm{pH} 8 \cdot 4)$. The gel slice was macerated and incubated at $37^{\circ} \mathrm{C}$ for $24 \mathrm{~h}$. After centrifugation, the supernatant fraction was freeze-dried and subjected to PAGE for $2 \mathrm{~h}$ (until a bromophenol blue marker moved $4 \mathrm{~cm}$ using an $8 \mathrm{~cm}$ long gel at $3 \mathrm{~mA}$ per gel). The gel was cut into $1 \mathrm{~mm}$ slices, and the radioactivity of each slice was measured.

\section{RESULTS}

\section{Presence of precursors of cytoplasmic $\alpha$ agglutination substance}

For analysis of the biosynthesis of AS, its labelling in $\alpha$ cells was measured. $S$. cerevisiae cells in nutrient-poor media generally lose sexual agglutinability. However, they retain high agglutinability in SC medium or other standard rich media, such as YHG and YPD (Yanagishima \& Yoshida, 1981; Yamaguchi et al., 1984). Therefore, SC medium was chosen for labelling throughout this study.

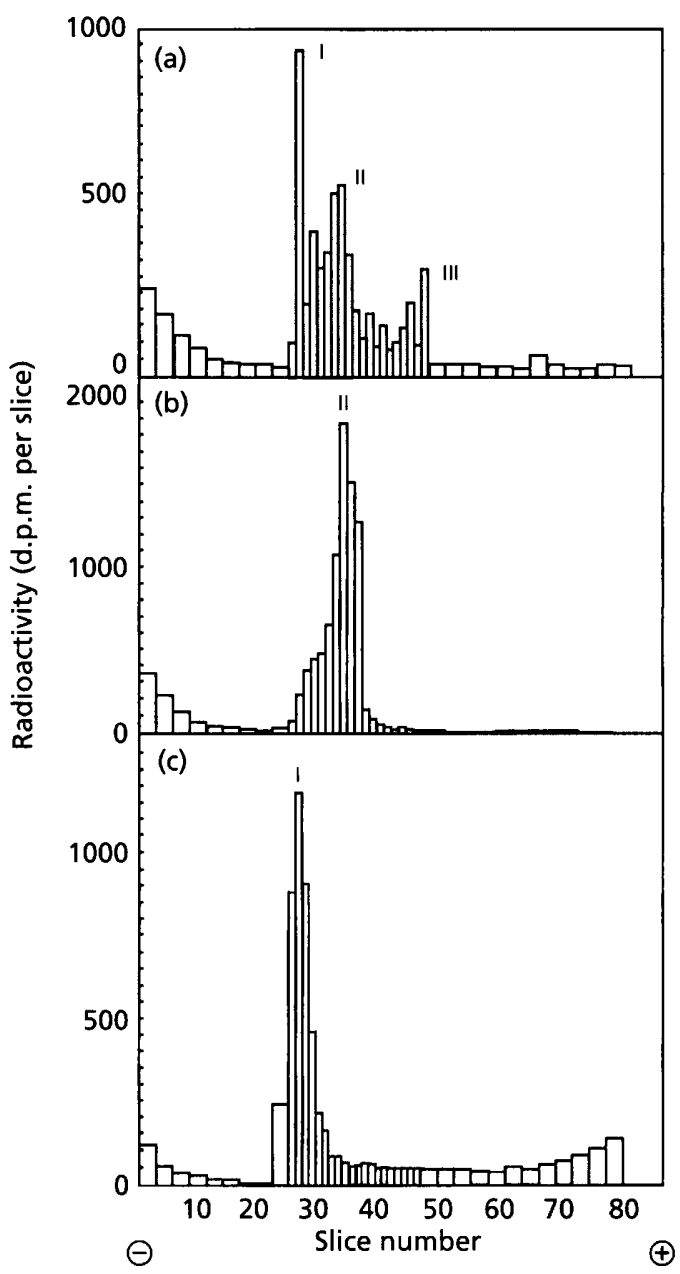

Fig. 1. Pulse label-chase analysis of the cytoplasmic $\alpha$ AS. T56 ( $\alpha)$ cells were subjected to $15 \mathrm{~min}$ pulse label/3 $\mathrm{h}$ chase with $\left[{ }^{35} \mathrm{~S}\right]$ methionine. Each $100 \mu \mathrm{l}$ of cell lysate was subjected to prolonged PAGE. The gel was cut into slices and analysed. (a) 5 min pulse label; (b) 5 min pulse label/10 min chase; (c) $15 \mathrm{~min}$ pulse label $/ 3 \mathrm{~h}$ chase. The values of radioactivity in doublethickness slices at the ends of the histogram are mean values of two activities. 


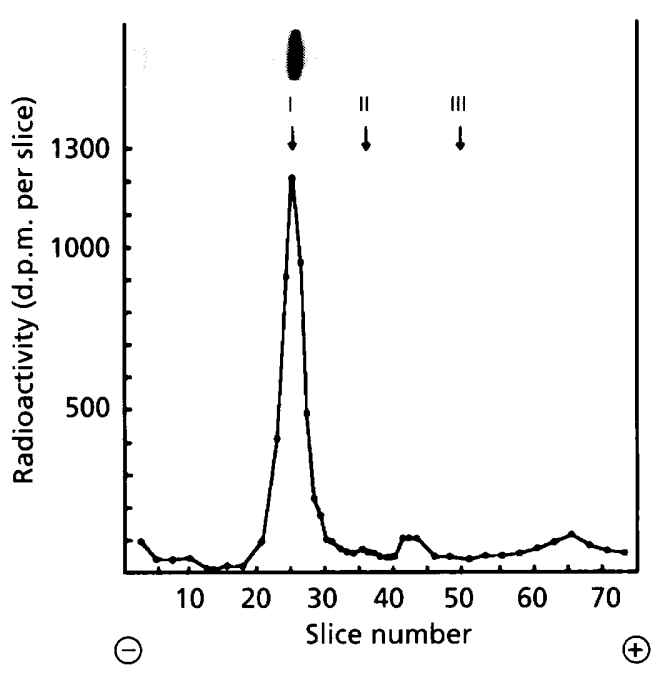

Fig. 2. Coincidence of $\left[{ }^{35} \mathrm{~S}\right]$ methionine-labelled band with purified cytoplasmic $\alpha$ AS. Purified c $\alpha$ AS $(10 \mu \mathrm{g})$ and $100 \mu \mathrm{l}$ $\left[{ }^{35} \mathrm{~S}\right]$ methionine-labelled cell lysate were subjected to prolonged PAGE and analysed. The gel stained with PAS reagent is shown at the top of the Figure. The gel was cut into $1 \mathrm{~mm}$ segments and the radioactivity of each segment was measured. Arrows I to III correspond to peaks I to III in Fig. 1.

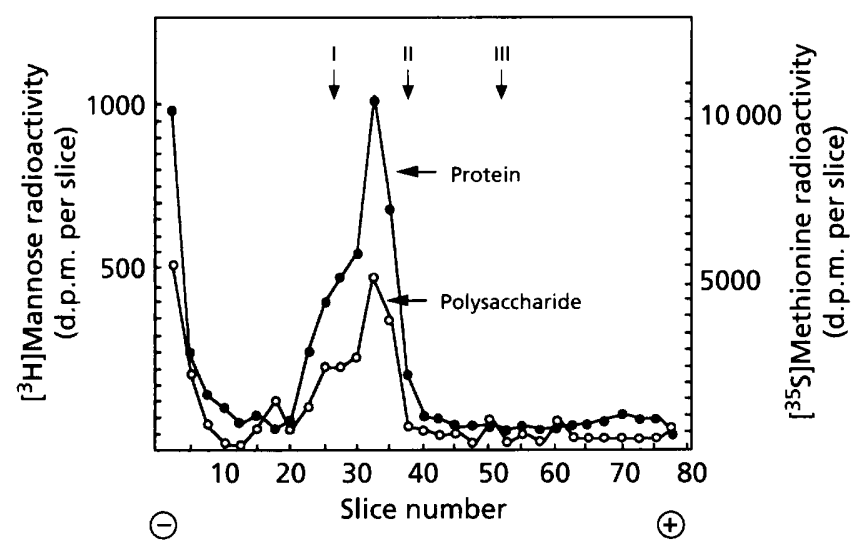

Fig. 3. Effect of puromycin on $\alpha A S$ synthesis. Protoplasts were labelled with $\left[{ }^{3} \mathrm{H}\right]$ mannose $\left(0.444 \mathrm{MBq} \mathrm{ml}^{-1}\right)$ for $1 \mathrm{~h}$. After washing twice with $0.8 \mathrm{M}$ sorbitol containing $200 \mathrm{mM}$ mannose, puromycin $\left(4 \mathrm{mg} \mathrm{ml}^{-1}\right)$ was added and the mixture was incubated for $1 \mathrm{~h}$. After washing twice with $0.8 \mathrm{M}$ sorbitol containing $200 \mathrm{mM}$ mannose, the protoplasts were labelled with $\left[{ }^{35} \mathrm{~S}\right.$ ]methionine for $1 \mathrm{~h}$. The double-labelled sample was separated by prolonged PAGE. Arrows I to III correspond to peaks $\mathrm{I}$ to III in Fig. 1. $\mathrm{O},\left[{ }^{3} \mathrm{H}\right]$ Mannose radioactivity; $\left[{ }^{35}\right.$ S] methionine radioactivity.

The cytoplasmic agglutination substance (cAS) was successfully separated as a single band by prolonged PAGE for $16 \mathrm{~h}$ since contaminant proteins ran through. This separation technique was based on the known low mobility of cAS in PAGE (Yamaguchi et al., 1982, 1984).

In order to determine the presence of AS precursors and their maturation process, the cells were subjected to a
$5 \mathrm{~mm}$ pulse label with $\left[{ }^{35} \mathrm{~S}\right]$ methionine, a $5 \mathrm{~min}$ pulse label followed by a $10 \mathrm{~min}$ chase, and a $15 \mathrm{~min}$ pulse label followed by a $3 \mathrm{~h}$ chase, all at $28^{\circ} \mathrm{C}$. The cytoplasmic extract of labelled cells was analysed by PAGE. After a 5 min pulse, three major peaks (I, II, III) were detected (Fig. 1a). Peak III diminished and peak II increased after a $10 \mathrm{~min}$ chase (Fig. 1b). After a $3 \mathrm{~h}$ chase, peak II decreased and was replaced by peak I, probably owing to an increased molecular mass (Fig. 1c). The results were interpreted as follows: the disappearance of peak I, which contains cAS, indicates the integration of AS into the wall, while the disappearance of peak III indicates its conversion into peak II, which is subsequently converted into peak I. The proposed conversion process is discussed in more detail later.

The cell extract from pulse-labelled $/ 3 \mathrm{~h}$ chase cells was mixed with purified caAS (Yamaguchi et al., 1982) and was then subjected to PAGE. After staining with PAS reagent to detect glycoproteins, the gel was cut into slices, and radioactivity measured. The peak of ${ }^{35} \mathrm{~S}$ labelling (peak I of Fig. 1) always coincided with the band stained with PAS reagent (Fig. 2). When cell extract labelled with $\left[{ }^{3} \mathrm{H}\right]$ mannose was analysed, the labelled peak again corresponded to peak I of Fig. 1 (data not shown). These data indicate that cAS contained a glycoprotein.

The labelled peak from $15 \mathrm{~min}$ pulse label $/ 3 \mathrm{~h}$ chase cells corresponded to cAS, which must have matured and migrated to the cell surface in about $3 \mathrm{~h}$ after synthesis. The identification of AS was confirmed by the detection of labelled wAS separated by the autoclave method (Yoshida et al., 1976) after a $3 \mathrm{~h}$ chase (data not shown).

\section{Effect of inhibitors on the synthesis of $\alpha$ agglutination substance}

Tunicamycin, a selective inhibitor of asparagine-linked glycosylation, was added to cells $30 \mathrm{~min}$ before they were pulse-labelled with $\left[{ }^{35} \mathrm{~S}\right]$ methionine. Tunicamycin treatment gave rise to broad peaks of labelling of higher electrophoretic mobility and thus of lower apparent molecular mass (data not shown). This suggests that the inhibition of $\mathrm{N}$-glycosylation results in a smaller AS size.

Puromycin treatment gave rise to broad peaks of $\left[{ }^{3} \mathrm{H}\right]$ mannose and $\left[{ }^{35} \mathrm{~S}\right]$ methionine labelling (Fig. 3). This was essentially the same electrophoretic profile as that seen after tunicamycin treatment. Because puromycin inhibits protein synthesis (Melcher, 1971), producing peptide fragments of various sizes, the broad peaks suggest that proteins with different sizes were linked to saccharides.

\section{Effect of temperature and sex pheromone on the synthesis of $\alpha$ agglutination substance}

T56 $(\alpha)$ cells lose agglutinability at $37^{\circ} \mathrm{C}$ because the $A G \alpha 1$ gene is temperature-sensitive (Yanagishima \& Yoshida, 1981). However, the agglutinability can be restored by the addition of pheromone, a process inhibited by cycloheximide (Tohoyama et al., 1979). The effect of 


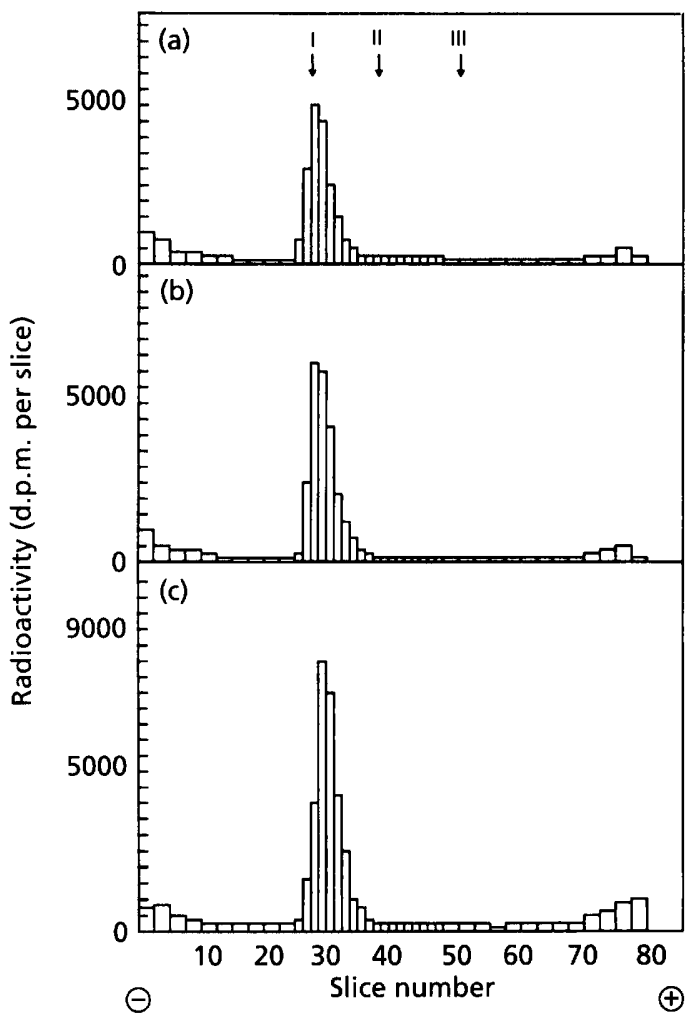

Fig. 4. Effects of temperature shift and a pheromone on the synthesis of $\alpha$ AS. T56 $(\alpha)$ cells cultured at $37^{\circ} \mathrm{C}$ were treated with a pheromone and analysed by prolonged PAGE. (a) $\alpha$ cells were cultured at $37^{\circ} \mathrm{C}$, and $30 \mu \mathrm{l}$ a pheromone was added to the cell suspension. After $30 \mathrm{~min}$ incubation, the cells were labelled with $\left.{ }^{35} \mathrm{~S}\right]$ methionine for $12 \mathrm{~h}$. (b) After $\alpha$ cells had been cultured at $37^{\circ} \mathrm{C}$, the cells were labelled with $\left[{ }^{35} \mathrm{~S}\right]$ methionine for $12 \mathrm{~h}$. (c) After $\alpha$ cells had been cultured at $28{ }^{\circ} \mathrm{C}$, the cells were labelled with $\left[{ }^{35} \mathrm{~S}\right]$ methionine for $12 \mathrm{~h}$. Arrows I to III correspond to peaks I to III in Fig. 1. The values of radioactivity in double-thickness slices at the ends of the histogram are mean values of two activities.

pheromone and temperature on AS synthesis was examined. As shown in Fig. 4, there were no distinct differences in the incorporation of radioactivity between the samples from cells cultured at $28{ }^{\circ} \mathrm{C}$, at $37^{\circ} \mathrm{C}$, and at $37^{\circ} \mathrm{C}$ in the presence of the a pheromone, although the incorporation of radioactivity was lower at $37^{\circ} \mathrm{C}$. In T556 $(\alpha / \mathbf{a})$ diploid cells, peak I (corresponding to cAS) had high radioactivity after culture at $28{ }^{\circ} \mathrm{C}$ (Fig. 5a) and at $37^{\circ} \mathrm{C}$ (data not shown).

To examine the biological activity of each peak I, the gels shown in Figs 1(c), 4 and 5 were cut into slices and the eluates of slices corresponding to the peak of radioactivity were tested. The eluate from peak I slices in agglutinable haploid cells showed about three times greater adsorption to a cells than to $\alpha$ cells, although there was some background caused by non-specific adsorption (data not shown).

These results indicate that both haploid and diploid cells synthesize peak I substance to which cAS anchors in agglutinable haploid cells.

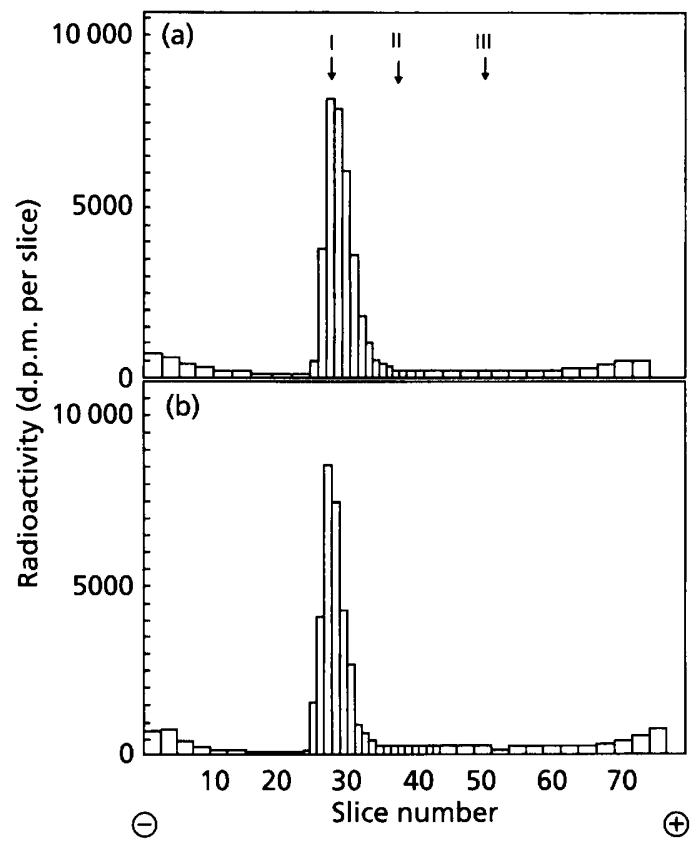

Fig. 5. The presence of peak I moiety in diploid cells. [35 ]Methionine-labelled cell lysate was prepared. Each $100 \mu \mathrm{l}$ of labelled lysate was subjected to prolonged PAGE and analysed. (a) Sample from T556 (diploid, a/ $\alpha$ ) cells; (b) sample from T56 $(\alpha)$ cells. Arrows I to III correspond to peaks I to III in Fig. 1. The values of radioactivity in double-thickness slices at the ends of the histogram are mean values of two activities.

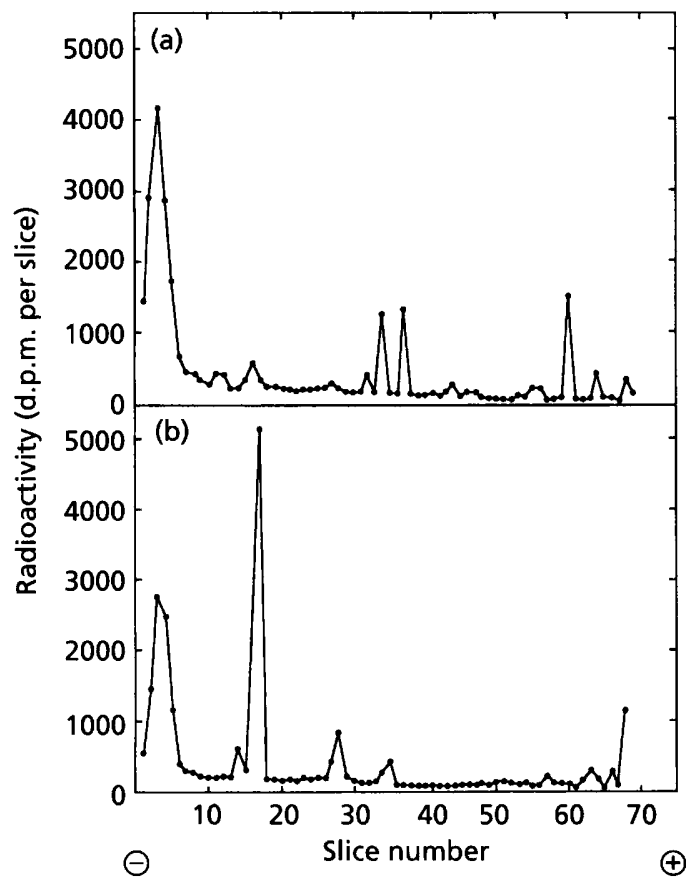

Fig. 6. Peptide mapping of peak I substance from haploid cells and diploid cells. The radioactive peak I from (a) T556 (diploid, $\mathrm{a} / \alpha$ ) or (b) T56 $(\alpha)$ cells in Fig. 5 was analysed by PAGE after trypsin digestion. 


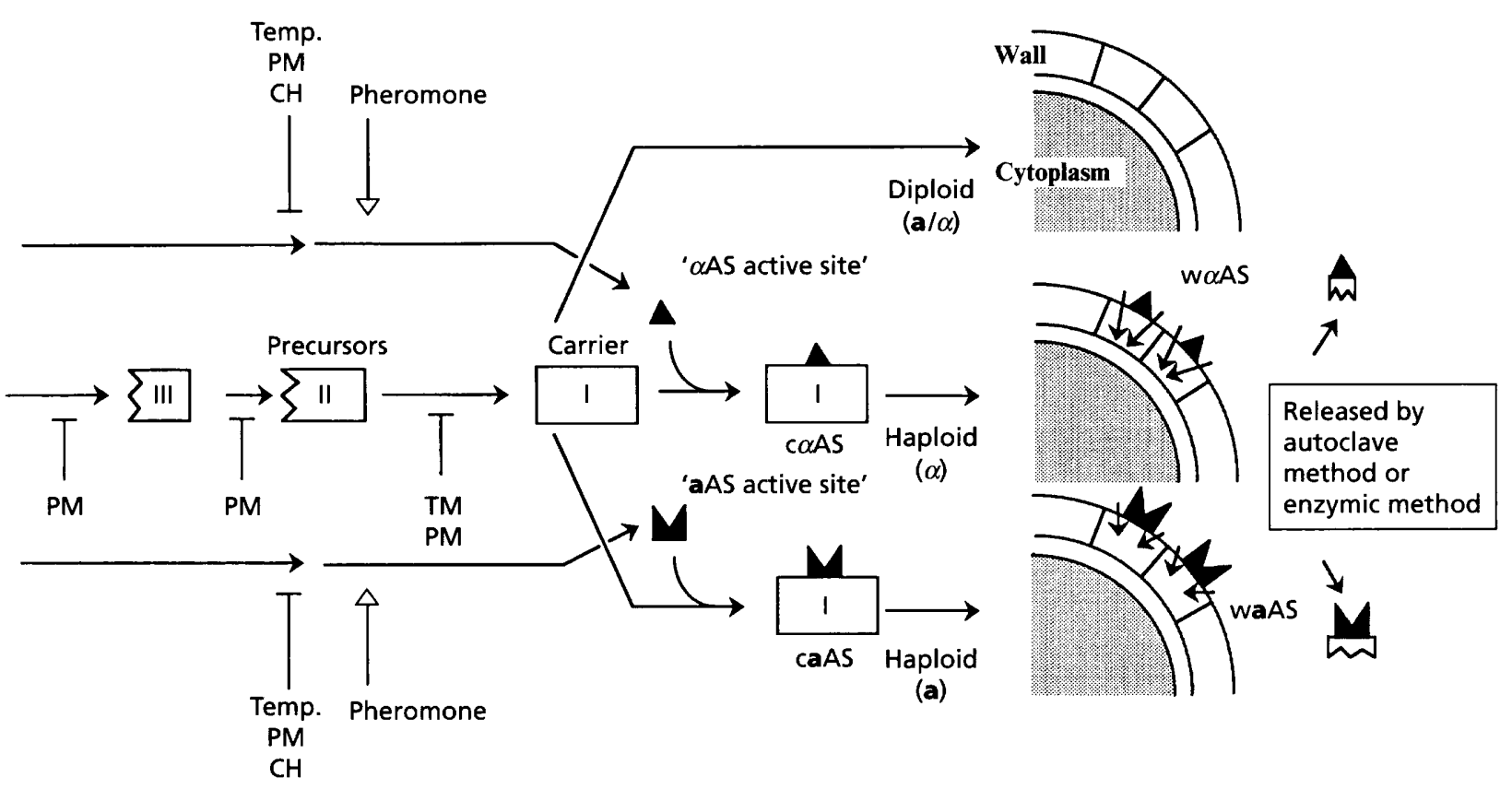

Fig. 7. Possible scheme of AS biosynthesis. In a and $\alpha$ haploid cells, and a/ $\alpha$ diploid cells, a common 'carrier' $(\square)$ and its precursor $(\Xi)$ are synthesized in the cytoplasm. The nascent active site of a $(\mathbf{M})$ or $\alpha(\Delta)$ protein moiety becomes cAS to link peak $I(\square)$ and is subsequently integrated into the cell wall. By the autoclave method or enzymic method (Yoshida \& Yanagishima, 1981), the AS substance on the cell wall is released with a part of the 'carrier'. Although the biosynthesis of nascent active sites themselves is influenced by inhibitors, we omitted it from this scheme. The T-type arrows ( $T$ ) indicate inhibition sites. The open arrows ( $\uparrow$ ) indicate activation sites. I, II, III correspond to peaks I, II, III in Fig. 1 . Abbreviations: $\mathrm{CH}$, cycloheximide; TM, tunicamycin; PM, puromycin.

\section{Peptide mapping of $\alpha$ agglutination substance}

The $\alpha$ AS has an active site in its protein moiety (Yanagishima \& Yoshida, 1981; Yamaguchi et al., 1982). In order to examine the difference between peak I substances from agglutinable haploid cells and nonagglutinable diploid cells (Fig. 5), these were subjected to peptide mapping. Haploid cells and diploid cells were labelled with $\left[{ }^{35} \mathrm{~S}\right]$ methionine, and after separation by PACiE with SDS, peak I was completely digested with trypsin. The peak I digests of haploid and diploid cells were distinct (Fig. 6), indicating that the peak I substances of agglutinable haploid cells and nonagglutinable diploid are different. The difference is due to the presence or absence of cAS in peak I.

\section{DISCUSSION}

While investigating the presence of precursors of AS, we found peak I substances in the cytoplasm of $S$. cerevisiae cells (Fig. 1). Peak I substances were radiolabelled in nonagglutinable haploid cells (Fig. 4) as well as in diploid cells (Fig. 5a), but AS activity in peak I was present in only agglutinable haploid cells. Since our prolonged PAGE cannot resolve subtle differences in the size of large glycoproteins with high carbohydrate content such as cAS (Yamaguchi et al., 1982, 1984) because of their very low mobility, we cannot separate AS active peak I from non-AS active peak I. However, peptide mapping clearly indicates that the peak I material from the diploid cells was not identical to that from haploid cells (which contains cAS substance) (Fig. 6). These results suggest that peak I contained not only AS but also other glycoproteins.

AS has a very high saccharide content and the active site is in the protein moiety (Yoshida et al., 1976; Yanagishima \& Yoshida, 1981; Yamaguchi $e t$ al., 1982, 1984). Lipke et al. (1989) showed that the $A G \alpha 1$ gene encodes a 650 amino-acid protein with a putative signal sequence, 12 possible $N$-glycosylation sites, and a high content of serine and threonine residues. We previously isolated active c $\alpha$ AS and estimated it to be about $200 \mathrm{kDa}$, with a carbohydrate content of more than $70 \%$ (Yamaguchi et al., 1982). The discrepancy in molecular size is due to the polysaccharide moiety in c $\alpha$ AS. Recent data by Cappellaro et al. (1991) are consistent with our high molecular mass of AS. They also indicate that the histidine-containing active protein region of $\alpha \mathrm{AS}$ is essential for interaction with aAS but the saccharides are not essential.

On the basis of the above evidence, it is plausible that wall-oriented large glycoproteins such as AS have a common core 'carrier' portion which consists of a large glycoprotein. Haploid T55 (a) and T56 ( $\alpha$ ) cells lose their sexual agglutinability at $37^{\circ} \mathrm{C}$ because the AS gene $(A G)$ is temperature-sensitive (Yanagishima \& Yoshida, 1981). In pulse-chase experiments at $37^{\circ} \mathrm{C}$, the turnover of the radioactivity of T56 $(\alpha)$ cells was essentially the same as 
shown in Fig. 1, where the experiments were done at $28{ }^{\circ} \mathrm{C}$, except that no radioactivity was apparent in peak I in Fig. 1(a) (data not shown). This indicates that the relatively high pulse radioactivity of peak I in Fig. 1(a) is due to the radioactivity of AS but not to the 'carrier'. The disappearance of peak I in Fig. 1(b) is explained by the integration of AS into the wall. The 'carrier' may mature through III to I. Both the 'carrier' and cAS ('carrier'bound AS active site) fall in peak I by prolonged PAGE. In other words, the binding of a relatively small AS active site may not increase the electrophoretic mobility because the size of the 'carrier' is estimated to be more than $140 \mathrm{kDa}$ with a carbohydrate content of more than $70 \%$ (Yamaguchi et al., 1984). After the active site of AS is covalently linked to the 'carrier', the matured AS now may be anchored into a cell wall. This is shown schematically in Fig. 7.

The puromycin experiment (Fig. 3) indicates that the 'carrier' for AS matured from its precursors, and its maturation required the covalent linking of newly synthesized protein. If no such common 'carrier core' existed in AS, newly synthesized proteins $\left({ }^{35} \mathrm{~S}\right.$ peak), present after the removal of puromycin, could not be linked to the glycoproteins $\left({ }^{3} \mathrm{H}\right.$ peak) synthesized before the addition of puromycin, so the peaks of ${ }^{35} \mathrm{~S}$ and ${ }^{3} \mathrm{H}$ would not be coincident with each other. However, ${ }^{35} \mathrm{~S}$ and ${ }^{3} \mathrm{H}$ were in fact reasonably coincident with each other over a relatively broad range (Fig. 3). This supports the idea of a 'common carrier' in Fig. 7.

In a study using secretion-deficient sec mutants (Tohoyama \& Yanagishima, 1987), a pheromone induced the agglutinability of wild-type cells at $37^{\circ} \mathrm{C}$ but not that of mutant cells. The study also indicated that both aAS and $\alpha$ AS may be secreted through a common path shared by invertase and acid phosphatase. This suggests that ASs as well as these secretory enzymes are concentrated in the top portion of the shmoo during conjugation. In fact, Watzele et al. (1988) have shown that the binding fragment of aAS localizes at the growing shmoo tip of a cells after exposure to $\alpha$ factor. Furthermore, the FUS product, which functions in the fusion of $\mathbf{a}$ and $\alpha$ cells to produce a zygote, shows a similar localization after exposure to pheromone (McCaffrey et al., 1987; Truehart et al., 1987). The shmoo tips are likely to correspond to the regions of the a cell and $\alpha$ cell that fuse to form a zygote; a high local concentration of proteins involved in fusion may therefore be required in this region to promote efficient fusion. Similar localization of $\alpha \mathrm{AS}$ in the shmoo tip by exposure to a pheromone could also account for the discrepancy between the observed 20-fold induction of $A G \times 1$ RNA and only a $1 \cdot 5$-fold increase in cellular agglutinability (Lipke et al., 1989; Wojciechowicz \& Lipke, 1989).

If our present data are considered together with the ASlocalization in shmoo tips (see above) and the rigidity of the cell wall, it is plausible that proteins, including AS, are not directly inserted into the cell wall but are inserted by a common glycoprotein 'carrier' (Fig. 7). The results presented here suggest that the biosynthesis of AS is different from those of glycoprotein enzymes. The matu- ration time of secretory invertase and carboxypeptidase $\mathrm{Y}$ in yeasts is in the range of 50-60 min (Novick et al., 1981; Stevens et al., 1982), while that of $\alpha$ AS was about $3 \mathrm{~h}$. Although no such precursors have been observed for the other secretory proteins discussed, the 'carrier' for AS matured stepwise through three precursors (peaks I, II, III) (Fig. 1).

Therefore, it is most likely that the nascent active site of AS is linked to a 'carrier' glycoprotein and subsequently the 'carrier' is introduced into specific portions such as the shmoo in cell walls.

\section{ACKNOWLEDGEMENTS}

This work was supported by grants to K. Yoshida and N. Yanagishima from the Ministry of Education, Science and Culture, Japan.

\section{REFERENCES}

Cappellaro, C., Hauser, K., Mrsa, V., Watzele, M., Watzele, G., Gruber, G. \& Tanner, W. (1991). Saccharomyces cerevisiae a- and $\alpha$ agglutinin: characterization of their molecular interaction. EMBO J 10, 4081-4088.

Lipke, P. N., Wojciechowicz, D. \& Kurjan, J. (1989). $A G \alpha 1$ is the structural gene for the Saccharomyces cerevisiae $\alpha$-agglutinin, a cell surface glycoprotein involved in cell-cell interactions during mating. Mol Cell Biol 9, 3155-3165.

MacKay, V. L. \& Manney, T. R. (1974). Mutations affecting sexual conjugation and related processes in Saccharomyces cerevisiae. II. Genetic analysis of nonmating mutants. Genetics 76, 273-288.

McCaffrey, G., Clay, F. J., Kelsay, K. \& Sprague, G. F., Jr (1987). Identification and regulation of a gene required for cell fusion during mating of the yeast Saccharomyces cerevisiae. Mol Cell Biol 7 , 2680-2690.

Melcher, U. (1971). Metabolism of puromycin by yeast cells. Biochim Biophys Acta 246, 216-224.

Novick, P., Ferro, S. \& Schekman, R. (1981). Order of events in the yeast secretory pathway. Cell 25, 461-469.

Stevens, T., Esmon, B. \& Schekman, R. (1982). Early stages in the yeast secretory pathway are required for transport of carboxypeptidase $Y$ to the vacuole. Cell 30, 439-448.

Strathern, J. N., Hicks, J. B. \& Herskowitz, I. (1981). Control of cell type in yeast by the mating type locus: the $\alpha 1-\alpha 2$ hypothesis. $J \mathrm{Mol}$ Biol 147, 357-372.

Suzuki, K. \& Yanagishima, N. (1986). Genetic characterization of an $\alpha$-specific gene responsible for sexual agglutinability in Saccharomyces cerevisiae: mapping and gene dose effect. Curr Genet 10, 353-357.

Tohoyama, H., Hagiya, M., Yoshida, K. \& Yanagishima, N. (1979). Regulation of the production of the agglutination substances responsible for sexual agglutination in Saccharomyces cerevisiae. Mol \& Gen Genet 174, 269-280.

Tohoyama, H. \& Yanagishima, N. (1982). Control of the production of the sexual agglutination substances by the mating type locus in Saccharomyces cerevisiae. Mol \& Gen Genet 186, 322-327.

Tohoyama, H. \& Yanagishima, N. (1987). Site of pheromone action and secretion pathway of a sexual agglutination substance during its induction by pheromone $\mathbf{a}$ in $\alpha$ cells of Saccharomyces cerevisiae. Curr Genet 12, 271-275.

Truehart, J., Boeke, J. D. \& Fink, G. R. (1987). Two genes required 
for cell fusion during yeast conjugation: evidence for a pheromoneinduced surface protein. Mol Cell Biol 7, 2316-2328.

Watzele, M., Klis, F. \& Tanner, W. (1988). Purification and characterization of the inducible a agglutinin of Saccharomyces cerevisiae. EMBO J 7, 1483-1488.

Wojciechowicz, D. \& Lipke, P. N. (1989). $\alpha$-Agglutinin expression in Sacbaromyces cerevisiae. Biochem Biophys Res Commun 161, 46-51.

Yamaguchi, M., Yoshida, K. \& Yanagishima, N. (1982). Isolation and partial characterization of cytoplasmic $\alpha$ agglutination substance in the yeast Saccharomyces cerevisiae. FEBS Lett 139, 125-129.

Yamaguchi, M., Yoshida, K. \& Yanagishima, N. (1984). Isolation, and biochemical and biological characterization of an a-matingtype-specific glycoprotein responsible for sexual agglutination from the crtoplasm of a-cells, in the yeast Saccharomyces cerevisiae. Arch Microbiol 140, 113-119.

Yanagishima, N. (1984). Mating systems and sexual interactions in yeast. In Cellular Interactions (Encyclopedia of Plant Physiology,
New Series, vol. 17), pp. 402-423. Edited by H. F. Linskens \& J. Heslop-Harrison. Berlin \& Heidelberg: Springer.

Yanagishima, N. \& Yoshida, K. (1981). Sexual interaction in Saccharomyces cerevisiae with special reference to the regulation of sexual agglutinability. In Sexual Interactions in Eucaryotic Microbes, pp. 261-295. Edited by D. H. O’Day \& P. A. Horgen. New York: Academic Press.

Yoshida, K., Hagiya, M. \& Yanagishima, N. (1976). Isolation and purification of the sexual agglutination substance of mating type a cells in Sacharomyces cerevisiae. Biochem Biophys Res Commun 71, 1085-1094.

Yoshida, K., Hisatomi, T. \& Yanagishima, N. (1989). Sexual behavior and its pheromonal regulation in ascosporogenous yeasts. J Basic Microbiol 29, 99-128.

Received 23 September 1993; revised 14 March 1994; accepted 10 May 1994. 